Копитіна Я.М.

\title{
Особливості застосування електронних засобів комунікації у системі ерготерапії слабозорих та незрячих осіб
}

\author{
Сумський державний педагогічний університет імені А.С. Макаренка, м. Суми, Україна
}

yana@kopytin.in.ua

\author{
Копытина Я.Н. \\ Особенности применения электронных \\ средств коммуникации в системе эрготерапии \\ слабовидящих и незрячих людей \\ Сумской государственный педагогический университет \\ имени А.С. Макаренко, г. Сумы, Украина
}

Kopytina Ya.M.

Features of application of electronic means of communication in the system of occupational therapy for visually impaired and blind people

Sumy State Pedagogical University named after AS Makarenko, Sumy, Ukraine

\section{Зв'язок роботи 3 науковими темами, планами}

Дослідження виконано згідно 3 колективною науково-дослідною темою кафедри здоров'я, фізичної терапії, реабілітації та ерготерапії Навчально-наукового інституту фізичної культури Сумського державного педагогічного університету імені А.С. Макаренка на 2020-2025 рр. «Теоретико-методологічні і організаційнометодичні проблеми здоров'я, фізичної терапії, реабілітації, ерготерапії та спеціальної освіти» (номер державної реєстрації 0120U100803).

\section{Встуі}

У більшості представників здорового населення думка про травми або захворювання, що супроводжуються втратою зору, як правило, викликає страх та тривогу перед своїм майбутнім та ставить під сумнів взагалі доцільність існування, оскільки через зоровий аналізатор людина отримує близько 80\% інформацію про оточуючий світ [1]. Часткове зниження гостроти зору (9D90.1-9D90.3) або повна сліпота (9D90.4-9D90.5) спонукають інші системи аналізаторів активізуватися у своїй роботі та реалізувати компенсацію зниженого або повністю відсутнього зорового аналізатора.

Система ерготерапії слабозорих та незрячих осіб спрямована на зменшення впливу інвалідності за рахунок створення максимально незалежних від зовнішніх факторів умов існування, а також здійснення (за потреби) процесу навчання, перенавчення та оптимізації видової діяльності. Завдяки розвитку науки і техніки, сучасні досягнення цифрових технологій дозволяють слабозорим та незрячим особам безперешкодно сприймати інформацію ззовні, допомагаючи орієнтуватися у просторі, спілкуватися із близькими та знайомими, користуватися соціальними мережами та мессенджерами, слухати музику та читати книги, переглядати фільми, що мають тифлокоментарі, вільно подорожувати, навчатися та працювати. Нові цифрові технології допомагають зрівняти можливості осіб, які мають інвалідність по зору із здоровими, створюючи віртуальні допоміжні платформи та електронні додатки, які розробляються відповідно до мети та завдань щодо потенційної цільової авдиторії користувачів.

Мета - провести аналіз функціоналу електронних додатків для мобільних телефонів, наручних годинників та персональних комп'ютерів, які розроблені та адаптовані спеціально під потреби та можливості слабозорих та незрячих користувачів.

\section{Матеріали та методи}

У дослідженні взяли участь 270 осіб із інвалідністю віком від 18 до 46 років, які мали тяжкі порушення зору або сліпоту. Вони проходили курс фізичної терапії на базі Західного реабілітаційно-спортивного центру Національного комітету спорту інвалідів України (с. Яворів, Турківський р-н, Львівська обл.) з 2016 по 2020 pp. Тривалість заїздів на реабілітаційно-спортивні збори становила по два тижня влітку та взимку, за виключенням літа 2020 року. Кількість пацієнтів із залишком зору складала 167 осіб (61,9\%), незрячих - 103 особи (38,2\%). Інвалідність першої групи мали 205 осіб $(75,9 \%)$, другої - 65 осіб $(24,1 \%)$. Програму фізичної терапії пройшли 145 жінок $(53,7 \%)$ та 125 чоловіків (46,3\%). Реабілітантів віком від 17 до 21 року було 30 осіб $(11,11 \%)$, у віковій групі $22-35$ років - 220 осіб $(81,48 \%)$, у віковій групі $36-55$ років - 20 осіб $(7,41 \%)$. Середній вік пацієнтів становив $28,6 \pm 5,12$ років.

За особливостями географічного поділу реабілітанти були з: Одеської обл. - 36 осіб (13,33\%), Львівської обл. - 32 особи (11,85\%), Черкаської обл. -25 осіб (9,26\%), Київської обл. - 24 особи $(8,89 \%)$, Харківської та Хмельницької обл. - по 15 осіб (5,56\%), 
Кіровоградської та Полтавської обл. - по 13 осіб (4,82\%), Волинської обл. - 12 осіб (4,45\%), Рівненської обл. - 10 осіб (3,7\%), Івано-Франківської обл. - 9 осіб (3,33\%), Дніпропетровської, Закарпатської, Житомирської, Чернігівської обл. та підконтрольної Україні території Донецької обл. - по 7 осіб (2,59\%), Сумської та Херсонської обл. - по 6 осіб $(2,22 \%)$, Запорізької та Тернопільської обл. - по 5 осіб $(1,85 \%)$, підконтрольної Україні території Луганської обл. - 4 особи $(1,48 \%)$, Чернівецької обл. - 3 особи $(1,11 \%)$, Вінницької обл. 2 особи $(0,74 \%)$.

\section{Результати дослідження та їх обговорення}

Під час реабілітаційно-спортивних заїздів із реаблітантами працювала мультидисциплінарна команда, яка включала у себе фізичних терапевтів, психологів, тренерів із скандинавської ходи, туризму, велосипедного спорту, із просторового орієнтування та електронних гаджетів. Усі дії тренерів та організовані ними заходи були чітко узгоджені між собою та доповнювали один одного.

Окремим блоком у розкладі було винесено цикл занять 3 «Сенсорних гаджетів». На цих заняттях реабілітантам проводився екскурс у сучасні цифрові технології, які допомагають слабозорим та незрячим особам вільно комунікувати із будь-якими членами суспільства при різних обставинах (родина, робота, хобі, спорт, шопінг, подорожі та ін.).

Перше заняття виявило, що 17 осіб (6,3\%) мають звичайні кнопкові телефони, які лише можуть озвучувати час та дату. Усі інші реабілітанти мали сенсорні, більш сучасні та зручні для користування слабозорими та незрячими власниками, телефони. На подальших заняттях здійснювалося опанування сенсорними гаджетами та електронними додатками, які допомагають у полегшенні навігації, розпізнавання візуальних об'єктів та для зв'язком iз волонтерами при зверненні за допомогою. Усім бажаючим користувачам допомагали інсталювати необхідні та корисні програми, розповідали про особливості меню та інтерфейсу, на практиці відпрацьовували викладений матеріал в розв'язанні наступних завдань: прочитати та відповісти на повідомлення у форматі тексту та аудіоповідомлення; розрізнити номінал купюри/монети; за підказками додатка та тактильними відчуттями розпізнати предмет; прочитати фрагмент аудіокниги, прослухати музичний трек, зорієнтуватися на місцевості (у приміщенні та на вулиці); звернутися за допомогою до волонтера через електронний додаток; заварити собі каву/чай та ін. Доцільно відмітити, що не існує якогось конкретного комплекту програм та електронних додатків, який би був універсальним для усіх слабозорих та незрячих користувачів. Оскільки реабілітанти живуть різним життям, мають різні професії, тож і відповідно вимоги щодо програмного забезпечення власних телефонів та персональних комп'ютерів висувалися різні.

Нижчезазначені у статті електронні додатки мають найбільший попит серед слабозорих та незрячих користувачів. Тому було проведено детальний аналіз функціоналу цих додатків та особливостей користування.
Додаток «Ве My Еуеs» широко використовується особами із вадами зору, оскільки він дозволяє долучити до допомоги у різних життєвих ситуаціях зоровий аналізатор волонтера. Суть даної розробки полягає у тому, що вона формує дві бази даних - добровольців та тих, хто потребує допомоги. Додаток є безкоштовним для скачування через PlayMarket та App Store, за 5-ти бальною шкалою оцінений у 4,7 бали. Доступний для Android та iOS [8].

Після інсталяції програми необхідно вказати до якої категорії користувачів відноситься власник телефону.

За необхідності здійснюється з'єднання із вільним волонтером, автоматично включається основна камера для демонстрації проблемної ситуації, яку самотужки не може вирішити особа через брак зору.

Під час реєстрації користувача особи-волонтера необхідно вказати мови, якими можливе вільне володіння $з$ метою підвищення зручності користування та комфортної комунікації між користувачами даного додатку.

Реєстрація вимагає від добровольців зазначити за місцевим часовим поясом той проміжок часу, коли волонтеру зручно відповідати на дзвінки.

На момент підготовки матеріалів до друку цей додаток був встановлений у більше ніж 246 тис. слабозорих та незрячих осіб та більше ніж у 4 млн добровольців-волонтерів (рис. 1).

Якщо не зважати на лінгвістичний аспект користувачів додатка, то в середньому на 1 особу, яка потребує допомоги зрячої людини, приходить 17 волонтерів. Тож, під час пошуку волонтера додаток знайде ту особу, яка буде вільною і здійснить з'єднання i подальшу допомогу/консультацію. Частими питаннями, iз якими звертаються до цього додатка $є$ розпізнавання грошових купюр, розпізнавання/співставлення необхідного кольору та фасону одягу, допомога під час роботи на комп'ютері, пошук загублених предметів, визначення строку придатності продуктів, визначення особливостей оточуючого середовища та ін.

Додаток MCT Money Reader розроблений для розпізнавання валют різних країн. $€$ безкоштовним для завантаження з PlayMarket та App Store, за 5-ти бальною шкалою користувачами оцінений у 3,6 бали. Доступний для Android та iOS. Є одним із найкращих серед додатків iз подібним функціоналом, проте необхідна щомісячна платна підписка для користування, або покупка необмеженої версії [11].

Для того, щоб розпізнати номінал купюри, об'єктив основної камери наводиться на купюру і після реєстрації номіналу звучить звуковий сигнал, який свідчить про закінчення операції розпізнавання. Додаток не здійснює розпізнавання монет, лише паперові банкноти. Українські гривні $є$ у базі даних додатку та розпізнаються без проблем (рис. 2).

Додаток «TalkBack» у телефонах, які працюють на операційній системі Android, починаючи зі 2 iï версії, дозволяє озвучувати екран - інтерфейс смартфона за допомогою жестової навігації. Він також є безкоштовним для завантаження 3 PlayMarket, та в більшості випадків встановлений за замовчуванням, має оцінку користувачів 4,3 бала [12]. 


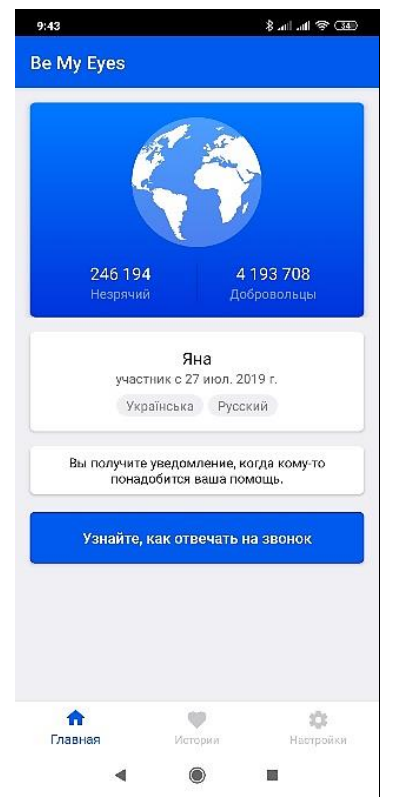

Рис. 1. Скріншот інтерфейсу додатка «Ве Му Еуеs»

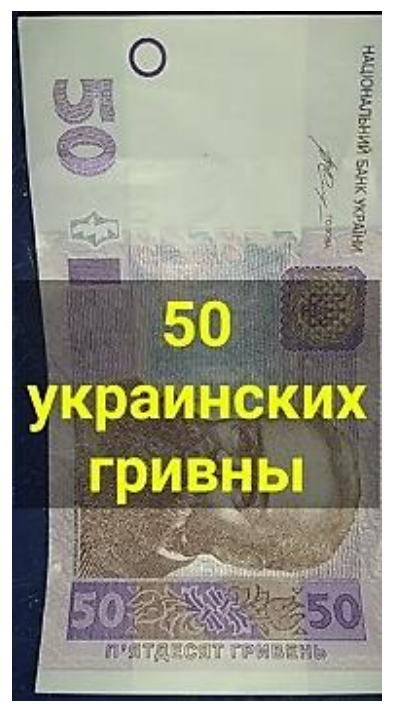

Рис. 2. Результат роботи додатку «МСТ Money Reader»

Додаток «VoiceOver» - елемент, що вбудований в операційні системи продукції компанії Apple, такі, як iOs, WatchOs, iPadOs, TiviOs. Встановлений за замовчуванням на всіх смартфонах, планшетах, смарт годинниках, ТБ приставках, не може бути видалений. Дозволяє озвучувати екран, інтерфейс за допомогою жестової навігації [9].

Додаток «Voice Dream Reader» $є$ платним (вартість програми становить приблизно \$15), одним із найкращих додатків для читання в аудіо форматі електронних книг. Ця програма є на $100 \%$ доступною для осіб із вадами зору, не зважаючи на те, що була розроблена без урахування спеціальних потреб слабозорих та незрячих осіб. Даний додаток $\epsilon$ еталоном для інших розробників схожих електронних платформ [2].

Для переміщення містом, особливо малознайомим або незнайомим, для слабозорих та незрячих осіб розроблені додатки-навігатори, які полегшують процес орієнтування у просторі та допомагають прокласти зручний маршрут у разі потреби. Додаток супутникової навігації «Lazarillo GPS for Blind» ( $\epsilon$ безкоштовним для скачування 3 PlayMarket та App Store), має оцінку користувачів 4,5 балів. Під час встановлення цього додатку на телефон відбувається запит дозволу на визначення геолокації, який необхідно підтвердити користувачеві. Програма містить наступні вкладки: «Транспорт», «Банки та банкомати», «Здоров'я», «Їжа», «Магазини», «Мистецтво та розваги», «Громадські будівлі», «Освіта», «Бари та клуби», «Жилі будинки». Дані вкладки полегшують пошук необхідного місця орієнтиру та створюють класифікацію усіх споруд та місць. Під час користуванням додатку «Lazarillo GPS for Blind» автоматично встановлюється місцезнаходження користувача, а під час вибору необхідного пункту призначення прописується найзручніший маршрут із вказанням відстані до нього і географічним напрямком руху. Інтерфейс додатку досить простий i зручний у користуванні, оскільки прописаний розробниками у білочервоній кольоровій гаммі, що робить контрастними «іконки» та дає змогу роздивитись їх для осіб із залишками зору.

$\mathrm{y}$ налаштуваннях цього додатку $\epsilon$ можливості коригування швидкості озвучування, $є$ синтезатор мови Google, сповіщення про рівень сигналу GPS, про втрату та відновлення зв'язку із супутниками GPS. Для зручності розуміння відстані між необхідними об'єктами користувачами можна обрати систему вимірювання метричну або Британську.

Формат об'яв про зміну напрямку руху можливий у трьох варіантах - відносний напрямок (наліво, направо), абсолютний (сторони світу) та за циферблатом стрілкового годинника.

У налаштуваннях пункту меню «Перехрестя» користувач може встановити за замовчуванням озвучування лише назв вулиць або озвучування лише перехресть вулиць.

Верхня панель меню має кнопку визначення поточного місцерозташування та пошук необхідного об'єкта. Нижня панель меню має кнопки «Дослідження», «Обране» та «Налаштування» [6].

Додаток розпізнавання візуальних об'єктів «Envision». Може бути завантажений 3 «PlayMarket» та «App Store». Мaє безкоштовний двотижневий демонстраційний період. Далі користувач може обрати кілька варіантів підписки, або придбати необмежену підписку. Програма потребує доступу до камер телефона та спалаху. Даний додаток є мультизадачним, оскільки має досить багато опцій. Так, він здатен здійснювати тифлокоментар картинки або фотографії, завдяки чому стає зрозумілим хто або що зображено на знімку. Якщо здійснити навчання програми із розпізнавання обличчя родичів чи знайомих, вона буде відразу ї називати поімені. Для цього розробники рекомендують зробити від 5 до 10 знімків обличчя конкретної людини, бажано у різних ракурсах для більш точного розпізнавання. Після цього за декілька секунд програма здійснить навчання себе i запам'ятає обличчя. У меню програми $є$ пункт 
«Бібліотека», де будуть збережені усі раніше запам'ятовані обличчя. «Envision» також можна використовувати для читання та розпізнавання зображення, із якими користувач стикається у інших додатках, таких, як Photos, Twitter, WhatsApp та ін. Для цього, вперше використовуючи дану опцію, необхідно натиснути «Додатково» у правому нижньому куті загального листа і додати «Envision It» до дій.

Додаток дозволяє розпізнати колір предмета (у налаштуваннях $€$ варіант Standard - 40 кольорів та Descriptive - 140 кольорів), що є доцільним у побуті під час одягання.

«Envision» уміє синтезувати текст у мовлення, автоматично визначає мову, на якій написаний текст. Уміє розпізнавати та читати охайно записаний рукописний текст або нотатки [10].

Вбудована опція збільшуваного скла дозволяє слабозорим особам збільшувати фрагменти тексту, які вони хочуть прочитати. Ступінь збільшення можна регулювати під особистісні потреби та функціональні можливості зорового аналізатора.

Функція сканування штрих-коду за допомогою звукового сигналу, який змінює свою частоту, допомагає розпізнати продукти, які мають штрих-коди. Після успішного сканування користувача додатка сповістять звуковим сигналом і відбудеться озвучування назви конкретного продукту. Для більш детальної інформації про продукт необхідно натиснути «Додаткова інформація» у додатку.

Розробники додатку потурбувались про здійснення контролю над роботою усіх опцій програми. Так, користувач може залишити відгук, або запросити виклик, перевірити облікові данні, налаштувати такі параметри, як розпізнавання тексту в автономному режимі, автоматичне визначення мови, конвертування тексту в мову.

Хоча додаток «Envision» $є$ досить функціональним, розробники радять щотижня перевіряти наявність оновлень програми або обрати опцію автоматичного оновлення.

3 метою контролю стану власного здоров'я у побуті зручно використовувати тонометри, термометри для тіла та повітря, глюкометри, ваги із вбудованим мовленнєвим виходом.

У повсякденному житті особами із вадами зору можуть використовуватися індикатори рівня рідини для незрячих (рис. 3). Оскільки під час приготування напоїв, як холодних, так і гарячих, цей індикатор дозволить попередити переливання через край чашки та потенційного опіку при використанні гарячої рідини. Індикатори можуть бути звуковими та віброзвуковими, які оснащені трьома контактами різної довжин. Частота звукового сигналу та тривалість вібрування будуть змінюватися у більшу при досягненні рівня рідини максимальної позначки ємкості. Індикатори можуть бути оснащені магнітами для того щоб кріпитися до холодильника і за першої потреби бути використаними [4].

Під час приготування їжі зручним у використанні буде тактильний кухонний таймер, який спеціально розроблений для слабозорих та незрячих осіб. Таймер є механічним приладом, на циферблаті якого кожні 15 хв позначені трьома випуклими крапками, кожні 5 хв - двома випуклими крапками, кожні 2,5 хв - однією випуклою крапкою. У центрі циферблата розташоване зручне реле для встановлення часу. Діаметр таймера 7 см, максимальний час таймера - 60 хв [3].

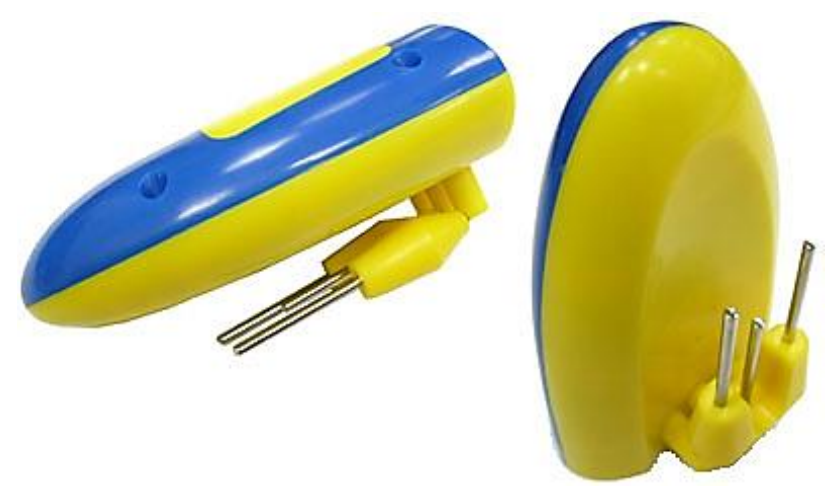

Рис. 3. Звуковий індикатор рівня рідини

На кухні серед безлічі ємкостей із різним вмістом допоможуть розмовляючі кришки для банок. Вони були спеціально розроблені для ідентифікації умісту банок або контейнерів. Легке записування та відтворення інформації спрощують життя та прискорюють процес вибору необхідного продукту. Такі кришки є багаторазовими, надають можливість записувати інформацію упродовж 20 сек. $\mathrm{C}$ варіанти кріплення до жестяних банок або кришок (окрім алюмінієвих), а також до звичайних контейнерів або пакетів за допомогою самоклеючого диска або спеціального ременя, який входить до комплекту. Живлення кришки здійснюється за допомогою 3 батарейок типу AG13. Діаметр кришки 7,9 см, глибина 2,2 см [5].

До кухонних приладів, які $є$ адаптованими для використання слабозорими та незрячими особами $\epsilon$ мультиварки, кухонні ваги тощо. Сучасна побутова техніка все частіше випускається із сенсорними кнопками, які важко побачити особам із порушенням зору. Проте, цифрові технології сьогодні дозволяють користуватися та управляти кухонною технікою дистанційно. Так, мультиварка REDMOND RMC-M92S має опцію керування процесом приготування їжі дистанційно с телефона за допомогою додатка Ready For Sky.

Цифровий маркер-диктофон «Touch Memo» допомагає слабозорим та незрячим людям знаходити необхідні для них предмети побуту (рис. 4). Пристрій, який нагадує формою ручку для письма, є портативним, легким та простим у застосуванні, не потребуючи ніяких спеціальних навичків користування. Завдяки цьому приладу можна самостійно без сторонньої допомоги диференціювати предмети, продукти харчування, одяг, лікарські засоби, документи, рахунки, кредитні карти тощо. У комплекті до нього входять 120 тактильних наліпок-етикеток, 40 гладеньких тактильних наліпокетикеток, 60 водонепроникних перезаписувальних тактильних наліпок-етикеток та 24 пластикові прищепки 
для кріплення до предметів гардеробу або різних пакунків. На цих етикетках буде міститися основна інформація про предмет, який вони маркерують. Під час користування «Touch Memo» необхідно наклеїти наліпку-етикетку до предмету, який має бути підписаний, натиснути кнопку запису на маркері-диктофоні, промовити необхідне повідомлення, записавши голосову мітку для даного предмета. Для того, щоб почути записану голосову мітку, необхідно лише торкнутися кінчиком ручки етикетки, і вона озвучить записану раніше мітку. Tоuch Memo має 2 Гб пам'яті, що вистачає на 83 години загального часу записів. Голосові мітки пишуться у форматі WAV, завдяки чому маркер-диктофон має відмінну якість звуку; містить опцію простого диктофона. Підключається до комп'ютера за допомогою USB 2.0, дозволяє зберігати архів голосових повідомлень на комп'ютер [7].

Заняття у тренажерній залі, яка оснащена тренажерами з електронікою, що мають Bluetooth зв'язок iз смарт годинником Apple Watch дає змогу особам iз вадами зору контролювати процес тренування, оцінюючи фізичний стан власника годинника при виконанні фізичної роботи певного виду. Про надмірне фізичне навантаження, або навпаки, замале, годинник буде повідомляти повідомленням та здійснювати запис динаміки фізичного стану.

Вищезазначені додатки були у топі програм, що користувалися найбільшим попитом серед реабілітантів. За вимогою здійснювався індивідуальний підбір програм, ї інсталяція та подальше навчання користуванню.

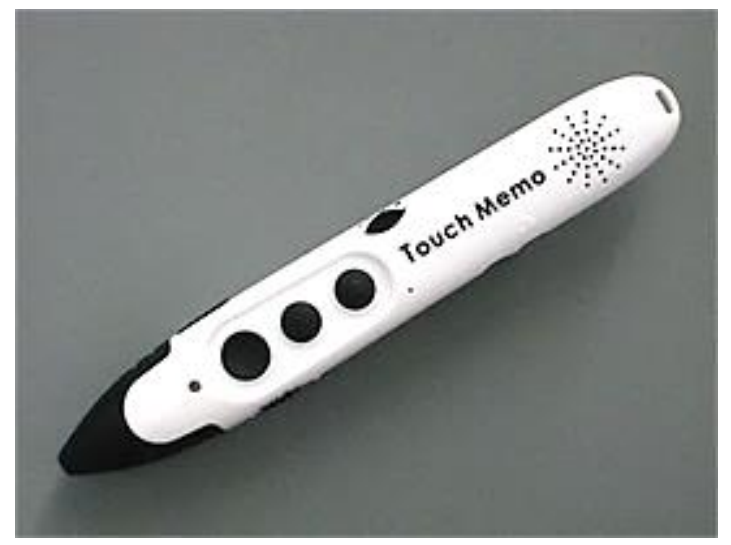

Рис. 4. Цифровий маркер-диктофон «Touch Memo»

\section{Висновки}

Сучасна слабозора чи незряча особа, маючи при собі смартфон із правильно підібраним набором необхідних програм, стає впевненою, незалежною від зовнішньої допомоги та зайвих непотрібних контактів із незнайомими людьми. Користуючись благами розвитку цифрової індустрії, можна самостійно робити покупки, роботу по дому, займатися дітьми, працювати, читати, слухати музику, спілкуватися із друзями, переміщатися містом та подорожувати, займатися спортом та слідкувати за станом власного здоров'я. Головною умовою всього $є$ лише одне - слідкування за новинками у сфері цифрових технологій та бажання їх використовувати.

\section{Література}

1. Нагорна АМ, Риков СО, Варивончик ДВ. Стан офтальмологічної захворюваності населення України. Офтальмологічний журнал. 2003;(3): 28-33.

2. Internet Voice dream [Електронний ресурс]. - Режим доступу: https://www.voicedream.com/.

3. Internet Таймер тактильний кухонний MAXI [Електронний ресурс]. - Режим доступу: https://www.smartaids.ru/catalog/product/taymer-taktilnyy-kukhonnyy-maxi.

4. Internet SmartAIDs [Електронний pecypc]. - Режим доступу: https://www.smartaids.ru/catalog/product/ indikator-urovnya-zhidkosti-zvukovibratsionnyy/.

5. Internet SmartAIDs [Електронний pecypc]. - Режим доступу: https://www.smartaids.ru/catalog/product/ govoryashchie-kryshki-dlya-banok-zapis-20-sekund/.

6. Internet Lazarillo [Електронний ресурс]. - Режим доступу: https://www.lazarillo.app/en/.

7. Internet Элита групп [Електронний ресурс]. - Режим доступу: https://www.elitagroup.ru/pages/prodTouchMemo.php.

8. Internet Ве My Еyes [Електронний pecypc]. - Режим доступу: https://www.bemyeyes.com/language/russian.

9. Internet iPhone [Електронний ресурс]. - Режим доступу: https:/www.apple.com/ru/accessibility/iphone/vision/.

10. Internet Envision [Електронний ресурс]. - Режим доступу: https://ru.letsenvision.com/.

11. Internet MCT Money Reader [Електронний ресурс]. - Режим доступу: https://play.google.com/store/apps/ details?id=com.mctdata.ParaTanima\&hl=en.

12. Internet Специальные возможности для Android [Електронний ресурс]. - Режим доступу: https://play.google.com/store/apps/details?id=com.google.android.marvin.talkback\&hl=ru.

\section{References}

1. Nahorna AM, Rykov SO, Varyvonchyk DV. Stan oftal'molohichnoi zakhvoriuvanosti naselennia Ukrainy. Oftal'molohichniy zhurnal. 2003;(3): 28-33.

2. Internet Voice dream [Electronic resource]. - Rezhym dostupu: https://www.voicedream.com/. 
3. Internet Taymer kukhonniy MAXI [Electronic resource]. - Rezhym dostupu: https://www.smartaids.ru/catalog/ product/taymer-taktilnyy-kukhonnyy-maxi/.

4. Internet SmartAIDs [Electronic resource]. - Rezhym dostupu: https://www.smartaids.ru/catalog/product/indikatorurovnya-zhidkosti-zvukovibratsionnyy/.

5. Internet SmartAIDs [Electronic resource]. - Rezhym dostupu: https://www.smartaids.ru/catalog/product/ govoryashchie-kryshki-dlya-banok-zapis-20-sekund/.

6. Internet Lazarillo [Electronic resource]. - Режим доступу: https://www.lazarillo.app/en/.

7. Internet Elita grupp [Electronic resource]. - Rezhym dostupu: https://www.elitagroup.ru/pages/prodTouchMemo.php.

8. Internet Be My Eyes [Electronic resource]. - Rezhym dostupu: https://www.bemyeyes.com/language/russian.

9. Internet iPhone [Electronic resource]. - Rezhym dostupu: https://www.apple.com/ru/accessibility/iphone/vision/.

10. Internet Envision [Electronic resource]. - Rezhym dostupu: https://ru.letsenvision.com/.

11. Internet MCT Money Reader [Electronic resource]. - Rezhym dostupu: https://play.google.com/store/apps/ details?id=com.mctdata.ParaTanima\&hl=en.

12. Internet Специальные возможности для Android [Electronic resource]. - Rezhym dostupu: https://play.google.com/store/apps/details?id=com.google.android.marvin.talkback\&hl=ru.

Дата надходження рукопису до редакції: 07.08.2020 p.

Мета - провести аналіз функціоналу електронних додатків для мобільних телефонів, наручних годинників та персональних комп’ютерів, які розроблені та адаптовані спеціально під потреби та можливості слабозорих та незрячих користувачів.

Матеріали та методи. У дослідженні взяли участь 270 осіб із інвалідністю віком від 18 до 46 років, які мали тяжкі порушення зору або сліпоту. Вони проходили курс фізичної терапії на базі Західного реабілітаційно-спортивного центру Національного комітету спорту інвалідів України (с. Яворів, Турківський р-он, Львівська обл.) 32016 по 2020 рр.

Результати. Досліджено функціональні можливості електронних додатків та цифрових технологій, розроблених для слабозорих та незрячих осіб. Для зв'язку із волонтерами та зверненням за допомогою до сторонньої особи розроблена програма «Be My Eyes». Для розпізнавання банкнот різних країн світу був розроблений додаток МСТ Мопеу Reader. Додатки «TalkBack» та «VoiceOver» створені для озвучування екрану телефона та усіх тактильних маніпуляцій користувача. Додаток «Voice Dream Reader» слугує для читання в аудіоформаті електронних книг. Додаток супутникової навігації «Lazarillo GPS for Blind» допомагає прокладати, обирати та корегувати необхідний маршрут та орієнтуватися на місцевості. Додаток розпізнавання візуальних об'єктів «Еnvision» дозволяє розрізнити, описати та зрозуміти що зображено та фото. Індикатори рівня рідини для незрячих дозволяють приготувати напій, не розливаючи рідину, попереджуючи побутові опіки. Електронні кухонні гаджети дозволяють безперешкодно готувати їжу та користуватися усім необхідним обладнанням. Цифровий маркер-диктофон «Тоuch Мето» допомагає слабозорим та незрячим людям знаходити необхідні для них предмети побуту. Новітні спортивні тренажери у поєднанні зі смарт годинниками дозволяють контролювати та моніторити стан здоров’я їх власника.

Висновки. Сучасна слабозора чи незряча особа, маючи при собі смартфон із правильно підібраним набором необхідних програм, може самостійно робити покупки, роботу по дому, займатися дітьми, працювати, читати, слухати музику, спілкуватися із друзями, переміщатися містом та подорожувати, займатися спортом та слідкувати за станом власного здоров'я.

Ключові слова: слабозорі особи, незрячі особи, комунікація, ерготерапія, цифрові технології, електронні додатки.

Цель - провести анализ функционала электронных приложений для мобильных телефонов, смарт часов и персональных компьютеров, разработанных и адаптированных специально под потребности и возможности слабовидящих и незрячих пользователей.

Материалы и методы. В исследовании приняли участие 270 слабовидящих и незрячих лиц с инвалидностью возрастом от 18 до 46 лет. Они проходили курс физической терапии на базе Западного реабилитационно-спортивного центра Национального комитета спорта инвалидов Украины (с. Яворов, Турковский р-он, Львовская обл.) с 2016 г. по 2020 г.

Результаты. Исследованы функциональные возможности электронных приложений и цифровых технологий, разработанных для слабовидящих и незрячих людей. Для связи с волонтерами и обращением за помощью к посторонним лицам разработана программа «Ве Му Еуеs». Для распознавания банкнот различных стран мира был разработан приложение MCT Money Reader. Приложения «TalkBack» и «VoiceOver» созданы для озвучивания экрана телефона и всех тактильных манипуляций пользователя. Приложение «Voice Dream Reader» служит для чтения в аудиоформате электронных книг. Приложение спутниковой навигации «Lazarillo GPS for Blind» помогает прокладывать, выбирать и корректировать необходимый маршрут и ориентироваться на местности. Приложение 
распознавания визуальных объектов «Envision» позволяет различить, описать и понять что изображено и фото. Индикаторы уровня жидкости для незрячих позволяют приготовить напиток, не разливая жидкость, предупреждая бытовые ожоги. Электронные кухонные гаджеты позволяют беспрепятственно готовить и пользоваться всем необходимым оборудованием. Цифровой маркер-диктофон «Тоuch Мето» помогает слабовидящим и незрячим людям находить интересующие их предметы быта. Современные спортивные тренажеры в сочетании со смарт часами позволяют контролировать и мониторить состояние здоровья их владельца.

Выводы. Современный слабовидящий или незрячий человек, имея при себе смартфон с правильно подобранным набором необходимых программ, может самостоятельно делать покупки, работу по дому, заниматься детьми, работать, читать, слушать музыку, общаться с друзьями, перемещаться по городу и путешествовать, заниматься спортом и следить за состоянием своего здоровья.

Ключевые слова: слабовидящие люди, незрячие люди, коммуникация, эрготерапия, цифровые технологии, электронные приложения.

Purpose - to analyze the electronic applications for mobile phones', watches' and personal computers' functionality, which were designed and adapted specifically for needs and capabilities of visual impaired and blind users.

Materials and methods. The are 270 people with disabilities aged 18 to 46 who had severe visual impairment or blindness who were participated in our research.

They underwent a course of physical therapy on the basis of the Western Rehabilitation and Sports Center of the National Committee of Disabled Sports of Ukraine (Yavoriv village, Turkiv district, Lviv region from 2016 to 2020 . The number of visually impaired consumers is 167 people (61.9\%), blind - 103 people (38.2\%). The disability of the first group had 205 people $(75.9 \%)$, the second group - 65 people $(24.1 \%)$. There are 145 women $(53.7 \%)$ and 125 men $(46.3 \%)$ were included in physical therapy process. There were 30 rehabilitators aged from 17 to $21(11.11 \%), 220$ in the age group $22-35$ (81.48\%), and 20 in the age group 36-55 (7.41\%). The mean age of patients was $28.6 \pm 5.12$ years. The duration of courses for rehabilitational and sports training was two weeks in summer and winter, except for the summer of 2020.

Results. The electronic applications' and digital technologies' functional capabilities for the visually impaired and blind are investigated was developed. The "Be My Eyes" program has been developed to communicate with volunteers and seek help from an outsider. The "MCT Money Reader" application was developed to recognize banknotes from around the world. The "TalkBack" and "VoiceOver" applications are designed to sound the phone screen and all tactile manipulations of the user. The "Voice Dream Reader" application is used to read e-books in audio format. The "Lazarillo GPS for Blind" satellite navigation application helps you map, select and adjust the required route and navigate the terrain. The "Envision" visual object recognition application allows you to distinguish, describe and understand what is depicted and the photo. Liquid level indicators for the blind allow you to prepare a drink without spilling liquid, preventing household burns. Electronic kitchen gadgets allow you to easily cook and use all the necessary tools. The digital marker-dictaphone "Touch Memo" helps visually impaired and blind people to find the household items they need. The latest sports simulators in combination with smart watches allow you to control and monitor the health of their owner.

Conclusions. A modern visually impaired or blind person, carrying a smartphone with the right set of necessary programs, becomes confident, independent of outside help and unnecessary contacts with strangers. With the benefits of the digital industry, you can shop, do housework, take care of children, work, read, listen to music, socialize with friends, travel around the city and travel, play sports and monitor your own health.

Key words: visually impaired persons, blind persons, communication, occupational therapy, digital technologies, electronic applications.

\section{Відомості про автора}

Копитіна Яна Миколаївна - кандидат наук з фізичного виховання і спорту, доцент, доцент кафедри здоров'я, фізичної терапії, реабілітації та ерготерапії, Навчально-науковий інститут фізичної культури, Сумський державний педагогічний університет імені А.С. Макаренка.

+380 (99) 014-96-62, yana@kopytin.in.ua. 